\title{
Seed dispersal of Solanum thomasiifolium Sendtner (Solanaceae) in the Linhares Forest, Espírito Santo state, Brazil
}

\author{
João Vasconcellos-Neto ${ }^{1,3}$, Lidiamar Barbosa de Albuquerque ${ }^{2}$ and Wesley Rodrigues Silva ${ }^{1}$
}

Received: June 9, 2008. Accepted: May 15, 2009

RESUMO - (Dispersão de sementes de Solanum thomasiifolium Sendtner (Solanaceae) na Floresta de Linhares, Espírito Santo, Brasil). O propósito deste estudo foi analisar a dispersão de sementes e o estabelecimento de Solanum thomasiifolium em uma área de vegetação de "nativo" no Estado do Espírito Santo, na costa do sudeste do Brasil. Dez espécies de aves, o cachorro-do-mato (Cerdocyon thous) e uma espécie de lagarto (Tropidurus torquatus) alimentaram-se de frutos de S. thomasiifolium e dispersaram sementes viáveis em suas fezes. A contribuição proporcional de cada um destes grupos na dispersão de sementes foi de $77 \%$ para aves, $19 \%$ para o cachorro-do-mato e $4 \%$ para o lagarto. Formigas também contribuíram com a dispersão de sementes. Mais sementes foram depositadas nas ilhas de vegetação do que nas áreas abertas vizinhas. As taxas de germinação de sementes oriundas de frutos (controle), fezes de aves, fezes do cachorro do mato e do lagarto foram, respectivamente, $64 \%, 64 \%, 53 \%$ e $80 \%$. As diferenças entre estas taxas foram todas significativas, exceto entre o controle e fezes de aves. Lagartos foram importantes como transportadores de sementes entre ilhas de vegetação próximas e defecaram uma grande proporção de sementes viáveis. As aves e o cachorro-do-mato não aumentaram a germinação de sementes, mas promoveram a dispersão sobre uma área maior. A arquitetura da planta, a produtividade de frutos, as características do fruto e a diversidade de frugívoros são importante no sucesso de $S$. thomasiifolium para colonização do habitat.

Palavras-chave: aves, cachorro-do-mato, deposição de sementes, frugivoria, germinação, lagarto

ABSTRACT - (Seed dispersal of Solanum thomasiifolium Sendtner (Solanaceae) in the Linhares Forest, Espírito Santo state, Brazil). The aim of this study was to analyse seed dispersal and establishment of Solanum thomasiifolium in an area of "nativo" vegetation in Espirito Santo state on the southeastern Brazilian coast. Ten species of birds, the crab-eating fox (Cerdocyon thous), and one species of lizard (Tropidurus torquatus) fed on S. thomasiifolium fruits and dispersed viable seeds in their faeces. The proportional contribution of each of these groups to seed dispersal was $77 \%$ (birds), $19 \%$ (crab-eating fox) and $4 \%$ (lizards). Ants also contributed to seed dispersal. More seeds were deposited in vegetation islands than in the surrounding open areas. Germination rates of seeds collected directly from fruit (control), bird droppings, the faeces of crab-eating foxes and lizards were, respectively, $64,64,53$, and $80 \%$. Differences among these rates were all significant, except between birds and control. Lizards were important as seed carriers between nearby islands and they expelled a higher proportion of viable seeds. Birds and the crab-eating foxes did not enhance seed germination, but promoted seed dispersal over a wider area. Plant architecture, fruit productivity, fruit characteristics and the diversity of frugivores are important for the success of S. thomasiifolium in habitat colonization.

Key words: birds, crab-eating fox, frugivory, germination, lizard, seed deposition

\section{Introduction}

Fruits are usually seasonal resources used by many animals as part of their diet, and because of their high level of carbohydrates or lipids, they are considered a rich energy source for frugivorous species (Martínez del Rio \& Restrepo 1993). In many communities, a large proportion of plants are dispersed by animals. In rain forests, 50 to $90 \%$ of the tree species produce fleshy fruits that are adapted to ingestion by mammals (Howe \& Smallwood 1982). Seed dispersal by vertebrates is fundamental for the reproductive success of many species of tropical plants. The means of biotic and abiotic dissemination are often associated with a plant's investment in the nutritional quality of its fruit, as well as its colour, shape and smell (Howe \& Westley 1988).

The dispersal of fruits is influenced by the behaviour, physiology and morphology of the frugivores (Izhaki et al. 1995). The manner in which the fruit is handled and processed, and how long it remains in the gut all affect the viability and quantity of seeds that are transported (Levey 1986; Schupp 1993). The rate of germination could also be affected in different ways depending on the animal dispersers and the time through gut passage (Rodriguez-Perz et al. 2005). The destiny of the seeds and their germination are affected both by the area in which the frugivores live and by their patterns of movement (Rowell \& Mitchell 1991). Thus, seeds may be moved far from the mother plant to microsites with physical and biological characteristics that enhance the probability of success in the germination and establishment of the seedling (Stiles \& White 1986). According to Sinha \& Davidar (1992), seed dispersal interferes in the recruitment pattern on a temporal and spatial scale, and has a definite influence on the structure and dynamics of plant communities. Thus, the study of the interactions between frugivores and plants, particularly the behaviour of the frugivores and the location where the seeds are deposited, their viability and seedling establishment are important for understanding the dynamics of colonization by pioneer and other species.

Solanaceae are important plants in many neotropical forests because of their colonization of treefall gaps and successional stages (Charles-Dominique et al. 1981; Nepstad et al. 1998; Tabarelli et al. 1999). Species of Solanaceae with fleshy fruit, especially from the genus Solanum, are mainly dispersed by bats (Iudica \& Bonacorso 1997; Galindo-González 1998; Passos et al. 2003). Few cases were related for non-flying mammals (Alexandre 1982; Facure \& Giaretta 1996; Bueno \& Motta-Junior

\footnotetext{
Departamento de Zoologia, Instituto de Biologia, Universidade Estadual de Campinas, Campinas, SP, Brazil

2 Graduate Program in Ecology, Depto de Zoologia, IB, Universidade Estadual de Campinas, Campinas, SP, Brasil

3 Corresponding Author: jvascont@unicamp.br
} 
2004), birds (Pijl 1972; Symon 1979; Murray et al. 1994; Avila et al. 1996; Nogales et al. 1999), and reptiles (Rick \& Bowman 1961; Nogales et al. 1998; Castro \& Galleti 2004). Solanum thomasiifolium is a pioneer shrub, with aculeate leaves, branches and stalk. Its fruits are ornithocoric. This species is distributed throughout the Brazilian states of Alagoas, Sergipe, Bahia, Minas Gerais and Espirito Santo (J. R. Stehmann, pers. comm.). This species was uncommon in the "nativo" vegetation (herbaceous, shrub-like vegetation arranged in sandy soil patches of the Atlantic rain forest) of the area studied from May 1989 to January 1995, after fire defoliated all the vegetation leaving only trunks of small trees. In July 1995, this area resprouted with young $S$. thomasiifolium growing mainly in the old vegetation islands. In July 1996, when the study of seed dispersal began, these plants had reached adult size, flowered and bore fruit; with a density of 871.6 ind./ha. Before the fire, these islands were scattered randomly over the landscape and provided favourable resting or feeding perches for birds, whose faeces may have enhanced the richness of the seed banks underneath the plants.

To understand the dispersal of Solanum thomasiifolium and colonization of the "nativo"vegetation, the characteristics of these plants (plant architecture and fruit traits) and the activity of the frugivores were investigated. Specifically, the following questions were addressed: a) How accessible are fruits? b) How much fruit was available per day on the plant and on the ground? c) What were the frugivorous species and what was their activity pattern? d) Where do the frugivores deposit their faeces with the ingested seeds? e) Was the germination rate of seeds that had passed through the gut of frugivores different from that of seeds which had not? f) Which animals were most effective dispersers of S. thomasiifolium? g) What was the relationship between the number of seeds and perch height and vegetation-island size?

\section{Material and methods}

Study area - This study was conducted from May 1989 to July 2000 at the Companhia Vale do Rio Doce Forest Reserve (RFCVRD) in Linhares, Espirito Santo state, southeastern Brazil (19 ${ }^{\circ} 06^{\prime}$ and $19^{\circ} 18^{\prime} \mathrm{S}, 39^{\circ} 45^{\prime}$ and $40^{\circ} 19^{\prime} \mathrm{W}$ ). The "nativo" consisted of patches of vegetation on sandy soil, and resembled an island in the middle of the Atlantic rain forest. Cacti, bromeliad-tussocks and herbs form patches of dense vegetation around shrubs and small trees, which alternate with open areas that sometimes consist of completely exposed sandy soil (Heinsdijk et al. 1965; Peixoto \& Gentry 1990).

In the first six years, we recorded data on the presence of S. thomasiifolium at four sites of "nativo" vegetation (Gavea, Barra Seca, BR- 101 road and Paraju) and only in the Paraju "nativo" we found a small number of individuals $(\mathrm{n}=5)$. The "nativo" vegetation at Paraju has an area of approximately 150 ha.

Seed dispersal evaluation - Fruit position in relation to the architecture of branches and leaves is considered a good trait to point to its frugivores and how they access the fruit (Pijl 1972; Uieda \&Vasconcellos-Neto 1985; Marinho-Filho \& Vasconcellos-Neto 1994). Fruits can be exposed outside the top (upper, below), and could also be at the same level or inside the foliage. To measure this trait, we created a "Fruit Exposition Index" (FEI) that is given by the following formula:
FEI $=2$ FD $/($ LS+LI $)$

Where: $\mathrm{FD}=$ fruit distance to the twig; $\mathrm{LS}=$ distance of the apices from the superior leaf to the twig; LI = distance of the apices from the inferior leaf to the twig.

When FEI $<1$, the fruit is hidden among the leaves; FEI = 1, the fruit is at the limit of the leaves; and FEI $>1$, the fruit is considered entirely exposed (Fig.1).
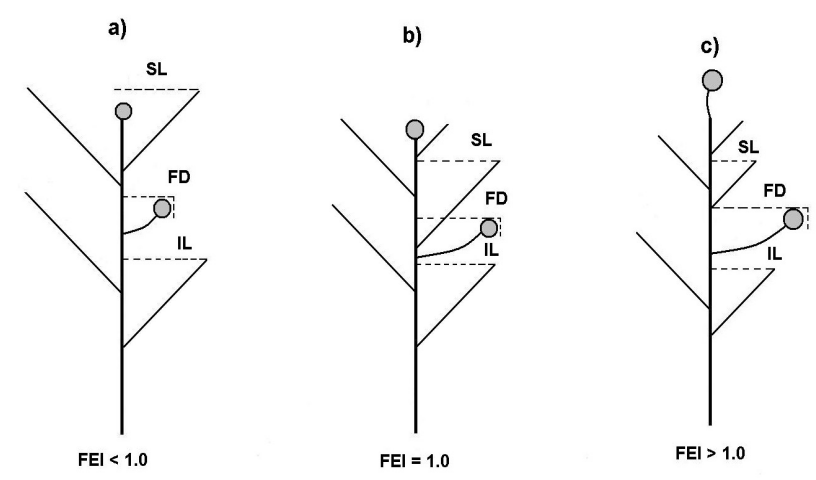

Figure 1. The diagram shows the "Fruit Exposition Index" (FEI) that is given by the formula: $\mathbf{F E I}=\mathbf{2} \mathbf{F D} /(\mathbf{L S}+\mathbf{L I})$; where: $\mathrm{FD}=$ fruit distance to the twig; $\mathrm{LS}=$ distance of the apex of the superior leaf to the twig; $\mathrm{LI}=$ distance of the apex of the inferior leaf to the twig. When FEI $<1$, the fruit is hidden among the leaves (a); FEI = 1, the fruit is in the limit of the leaves (b); and to FEI $>1$, the fruit is considered entirely exposed (c).

Field data on seed dispersal were recorded during July and the beginning of August 1996. As fruit traits are very important in studies of seed dispersal, the size and weight of $S$. thomasiifolium ripe fruit $(\mathrm{n}=30)$ collected from 30 different individuals were measured, along with the amount of sugar (registered with a refractometer) and the number and total weight of seeds per fruit. We also measured the length of the fruit peduncle and the cup, considering that the fruit is removed with a piece of the peduncle and the cup.

To assess the availability of ripe fruits per day per plant and the proportion of ripe fruits that fell to the ground per day, 27 plants were randomly marked and observed for five consecutive days. Fruits on each plant were covered with voile, and the number of unripe (green), almost ripe (yellow) and ripe (red) fruits on the plant or grown was recorded daily. The number of fruit that fell per day was also recorded from the same plant covered with voile, because fruits on the ground could be removed by frugivores. The daily rate of fruit removal was determined by marking 31 plants at random (at least $10 \mathrm{~m}$ from each other, usually in the vegetation islands) and recording the number of ripe fruit at dawn and the number of fruits that were removed by dusk.

The frugivores were identified by direct observation with the aid of binoculars in the case of birds, and also indirectly based on faeces, footprints, beak marks or marks left by lizards' teeth. To identify the latter, fruit models (with a bright orange-red colour), prepared from nontoxic plaster, were placed on the ground under S. thomasiifolium plants. The foraging activity of birds was observed in the morning, when frequency and eating behaviour of each species were recorded for two consecutive mornings (July 1996) to quantify the relative importance of each bird species as a seed disperser. The observer walked and stopped to look for birds feeding on Solanum fruits on a random transect among vegetation islands, for five hours each morning.

The rate of fruit removal on the ground by frugivores was assessed in July 1996, with an experiment carried out from 8:30 a.m. to 1:00 p.m. Ninety-nine S. thomasiifolium plants were randomly marked and one mature fruit was placed under each plant $(50 \mathrm{~cm}$ from the stem, and $10 \mathrm{~m}$ distant from the others). Plants were visited every hour to record the number of removed fruits. Each removed fruit was replaced by another so that during each survey the total number of available fruits was always the same. In the second survey (10:30 a.m. onward), plaster models of ripe fruits (mimics) were placed near real fruits to assess (based on teeth marks) whether lizards (Tropidurus torquatus) or birds were removing $S$. thomasiifolium fruits from 
the ground. The models that had marks on them or those that disappeared were replaced. The results from this experiment were analyzed using the chi-square test. In the same area, Vasconcellos-Neto et al. (2000) used plaster models of ripe fruits of Melocactus violaceous (Cactaceae) in an experiment with Tropidurus torquatus to verify how fruit traits were being used by the lizard to located fruits. This study showed that this method was appropriate. During the experiment to assess fruit removal from the ground (from 8:30 a.m. to 1:00 p.m.), the activity period of $T$. torquatus was determined based on 20 min recordings separated by one hour intervals. We would like to know if lizards were active in the absence of fruits on the ground and plaster models of $S$. thomasiifolium could indicate the frugivores by teeth marks.

Ants could remove pieces of ripe fruit containing seeds from plants or from the ground. Ant nests could be found in the "nativo", with S. thomasiifolium seeds in the refuse pile. To evaluated the role of ants as seed dispersers, nests were marked $(\mathrm{n}=33)$ and the Myrmicinae species identified in a 2.5 ha area in July 1998. For each spotted nest, the presence of $S$. thomasiifolium seeds in the refuse pile was recorded. Focal observations were made on ant behavior $(\mathrm{n}=5)$. For each nest where $S$. thomasiifolium seeds were spotted, the distance between the nest and the closest $S$. thomasiifolium individual was measured, as an estimate of the minimal seed dispersal distance.

The sites of faeces deposition by frugivores feeding on S. thomasiifolium were determined by searching vegetation islands and open areas. Frugivores were identified based on the characteristics of their faeces. Faeces of frugivorous birds typically occur on leaves and branches or under perches, and have a pasty aspect, sometimes showing shades of white because of diluted urate. Faeces of T. toquatus are small, compact and cylindrical, and are approximately $1 \mathrm{~cm}$ long with a terminal area of urate (Figueira et al. 1994). Faeces of Cerdocyon thous are similar to those of a medium size domestic dog, and are isolated or in toilets. The presence of fur in the faeces of this species and its footprints are helpful in the study of Facure \& Giaretta (1996). Only intact faeces were considered when calculating the number of seeds per faeces. Faeces found on toilets or under perches could not be individualized, and in this case, only the total number of seeds for each frugivores' group were counted

Based on observations in July 1995 in the Paraju "nativo", the period in which S. thomasiifolium plants were developing (especially in old patches), the number of seeds, and the dispersers involved were recorded for open areas and in vegetation islands. This was done by examining the ground surface of open areas, and the ground and leaves of 30 vegetation islands. The size of each patch was also measured (length and width), as well as the height of the tallest perch (shrubs and small dry trees). Eighty-eight patches $1 \mathrm{X} 2 \mathrm{~m}$ in size were randomly sampled in open areas, so that the total size of open areas was equivalent to that of the "nativo" patches.

Assuming that higher perches were visited more often by birds, the relationship between perch height and the total number of S. thomasiifolium seeds in faeces was determined. The relationship between the number of seeds and the size of the shrubs was also examined since larger shrubs can shelter a greater number of frugivores. Perch height and shrub size are correlated to plant age and growth in an area of the "nativo" vegetation island. We used Sperman's correlation coefficient in all these tests (Sokal \& Rohlf 1995).

S. thomasiifolium seeds obtained directly from fruits and from faeces of birds, lizards and crab-eating foxes were used in the germination experiments. Seeds were germinated on high absorption paper in sterile glass plates with constant light at room temperature for three months. The germination experiment was run from March to May 1998, using the following groups: a) 100 control seeds (fruit), b) 100 seeds from bird faeces, c) 100 seeds from Cerdocyon thous faeces, and d) 75 seeds from Tropidurus torquatus faeces. During daily observations, the seeds that germinated were removed in order to minimize any inhibitory effect on the germination of other seeds. Germination was defined as the emergence of the radicle. The results of this experiment were analyzed using two tests; the chi-square test to compare germination rates and the Kolmogorov-Smirnov non-parametric test (Sokal \& Rohlf, 1995) to compare the cumulative germination curves.

\section{Results}

Solanum thomasiifolium has several upward branches oblique to the stem, and some hanging branches, close to the ground (Fig. 2B). The distance from secondary branches to the fruit was $44.35 \pm 19.89 \mathrm{~cm}(\mathrm{n}=41)$. This distance was too big for smaller birds to perch on these branches, a problem aggravated by the number of thorns. Fruits remain between the leaves $(\mathrm{FEI}=0.43)$ and, due to leaf spacing and insertion angle, fruits can be seen and reached by the birds.

Solanum thomasiifolium produced round fruits $(1.2 \mathrm{~cm}$ in diameter) with approximately 24 small seeds each $2 \mathrm{~mm}$ in diameter. During ripening, fruits became orange-yellowish (from the first to second day) and then red (like tomatoes). Ripe fruits had a sweet flavour, with $78 \%$ of its weight corresponding to the pulp and $22 \%$ to the seeds (Tab. 1). Ripe fruits remained attached to the plant for at least one week. Few ripe fruits fell to the ground with their peduncles (without prickles). Fruit availability was approximately 6 fruits per plant per day. Around $20 \%$ of the fruits were removed by frugivores within a period of one day (Tab. $2 \mathrm{~A}$ ), and only $4.3 \%$ of ripe fruits fell naturally (Tab. $2 \mathrm{~B}$ ). Consequently, at least $95.7 \%$ of ripe fruits were removed from the plants by frugivores, mainly birds.

Ripe $S$. thomasiifolium fruits were consumed by 10 bird species (Tab. 3), one mammalian species (crab-eating fox, Cerdocyon thous) and one lizard species (Tropidurus torquatus). Two Myrmicinae ant species (Attini tribe)

Table 1. Characteristics of Solanum thomasiifolium fruits $(n=30)$, including fruit exposition index (see text; $n=40$ ). We used wet weight for fruits and seeds.

\begin{tabular}{lcc}
\hline FRUIT & $\overline{\boldsymbol{X}} \pm \mathbf{\text { sd }}$ & Min-Max \\
\hline Length $(\mathrm{cm})$ & $1.22 \pm 0.11$ & $0.97-1.36$ \\
Width $(\mathrm{cm})$ & $1.25 \pm 0.10$ & $1.0-1.4$ \\
Peduncle $(\mathrm{cm})$ & $0.81 \pm 0.14$ & $0.52-1.13$ \\
Cup $(\mathrm{cm})$ & $0.34 \pm 0.04$ & $0.29-0.44$ \\
Weight of fruit without peduncle $(\mathrm{g})$ & $1.10 \pm 0.25$ & $0.63-1.6$ \\
Weight of peduncle and cup $(\mathrm{g})$ & $0.09 \pm 0.02$ & $0.06-0.13$ \\
Number of seeds & $24 \pm 6.71$ & $11-35$ \\
Weight of seeds (g) & $0.24 \pm 0.07$ & $0.1-0.35$ \\
Sugar concentration (\%) & $18.4 \pm 1.78$ & $15.8-22.4$ \\
Fruit exposition index (FEI) & $0.43 \pm 0.16$ & $0.22-0.89$ \\
\hline
\end{tabular}

Table 2. Mean number of ripe Solanum thomasiifolium fruit natural conditions per plant and the mean removal rate of exposed fruit (A) where leaves were removed, the mean fall rate of bagged fruit (B), and the mean rate of bagged fruit bitten by Attini ants.

\begin{tabular}{lcc}
\hline A - Exposed fruit (n= 27 plants) & $\overline{\boldsymbol{X}} \pm \mathbf{S D}$ & $\mathbf{N}$ \\
\hline Ripe fruit/day/plant & $5.77 \pm 5.06$ & 179 \\
Removed fruit /day/plant & $1.15 \pm 1.77$ & 35 \\
Not-removed fruit/day/plant & $4.65 \pm 4.15$ & 144 \\
& & \\
B - Bagged fruit (n= 31 plants) & $\mathbf{0}$ & $\mathbf{N}$ \\
Ripe fruits & 100 & 533 \\
Fallen ripe fruits/day/plant & 4.31 & 23 \\
Ripe fruits bitten by Attinae & 3.38 & 18 \\
\hline
\end{tabular}


Table 3. Foraging frequency and behaviour of bird species fed on Solanum thomasiifolim fruits.

\begin{tabular}{|c|c|c|c|}
\hline Species & Behavior & Relative frequency $(\%)$ & Number of visits \\
\hline Pteroglossus aracari (Ramphastidae) & $\begin{array}{l}\text { Flight, } \\
\text { Perch }\end{array}$ & $\begin{array}{c}7.7 \\
92.3\end{array}$ & $\begin{array}{c}1 \\
12\end{array}$ \\
\hline Carpornis melanocephalus (Cotingidae) & undet. & & 1 \\
\hline Pipra rubrocapilla (Pipridae) & undet. & & 1 \\
\hline Pitangus sulphuratus (Tyrannidae) & $\begin{array}{l}\text { Flight, } \\
\text { Ground }\end{array}$ & $\begin{array}{l}50 \\
50\end{array}$ & $\begin{array}{l}1 \\
1\end{array}$ \\
\hline Tyrannus melancholicus (Tyrannidae) & Fluttering & 100 & 1 \\
\hline Euphonia violacea (Emberizidae) & Fluttering & 100 & 15 \\
\hline E. xanthogaster (Emberizidae) & Fluttering & 100 & 10 \\
\hline Ramphocelus bresilius (Emberizidae) & $\begin{array}{c}\text { Fluttering, } \\
\text { Ground, } \\
\text { Perch }\end{array}$ & $\begin{array}{l}71.4 \\
14.3 \\
14.3\end{array}$ & $\begin{array}{l}5 \\
1 \\
1\end{array}$ \\
\hline Schistochlamys melanopis (Emberizidae) & $\begin{array}{c}\text { Fluttering, } \\
\text { Ground, } \\
\text { Perch }\end{array}$ & $\begin{array}{l}50 \\
25 \\
25\end{array}$ & $\begin{array}{l}2 \\
1 \\
1\end{array}$ \\
\hline Saltator maximus (Emberizidae) & Flight & 100 & 1 \\
\hline
\end{tabular}

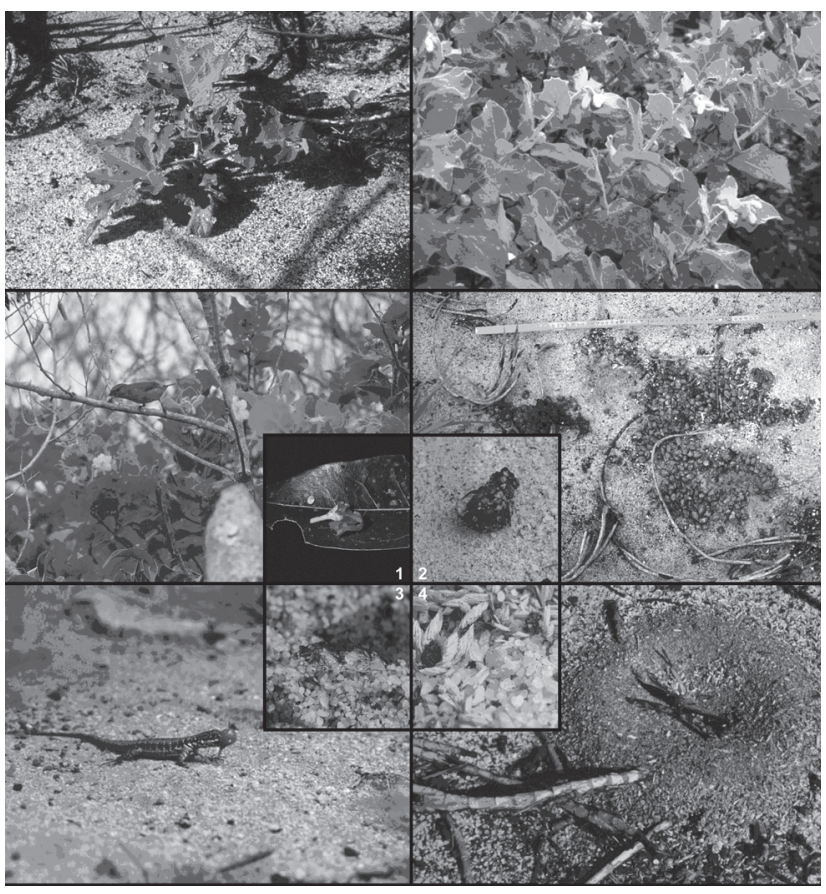

Figure 2. (A-F;1-4). (A) Young individual of Solanum thomasiifolium (= S.t) growing in the "Nativo"vegetation (Paraju) at RFCVRD in Linhares, Espirito Santo State, Brazil in July 1995. B. Adult individual of S. thomasiifolium ( 2 $\mathrm{m}$ height) with flowers and one ripe fruit in July 1996. C. A female bird of Euphonia sp. on a perch, feeding on a fruit of S. thomasiifolium in July 1996 (1. faeces of bird with seed and a piece of fruit of $S$. thomasiifolium). D. Toilets of crab-eating fox (Cerdocyon thous) palm and S. thomasiifolium seeds (2. faeces of Cerdocyon thous with seeds of S.t). E. The lizard Tropidurus torquatus feeding on a ripe fruit of $S$. thomasiifolium that fell on the ground (3. faeces of $T$. torquatus with seeds of S.thomasiifolium). F. A nest of Attini ant with a dump around it. (4. details of the dump with pieces of vegetables and in the center one seed of S. thomasiifolium).

Trachymymex sp. and Mycocepurus goeldii could also be responsible for the dispersal of seeds, as they were placed around their nests (Fig. 2F).

The most common birds were Euphonia violacea and E. xanthogaster (both Emberizidae), Pteroglossus aracari (Ramphastidae), and Ramphocelus bresilius (Emberizidae). Fruits were collected during fluttering (in many emberezids), flying (in tiranids) or by using a neighbouring plant as a perch (Pteroglossus aracari) (Tab. 3). Some fruits that fell to the ground were collected by emberezids. After grabbing the fruit, all the birds flew to a perch.

The behaviour of birds feeding on fruits varied from one species to another: picked the fruit while flying and/or fluttering or while on the ground, and then, returned to the perch to eat it. The most frequent species picked the fruit while fluttering and carried it to a perch to eat. In some cases, the fruit succeeded while still on the plant, especially when not completely ripe. Another foraging strategy consisted of landing on a neighbouring shrub and eating the ripe fruit that was at a reachable distance. Others species observed, but at a lower frequency, all of them feeding on fruits while on the perch (Tab. 3). Although these data showed the relative contribution of each species of bird as seed dispersers, these same frugivores were seen feeding on ripe fruits during the entire time of our studies.

The experiments involving ripe fruits and plaster models placed on the ground indicated that more fruits were removed than models $\left(\chi^{2}=4 ; p<0.05\right)$. Fruit models (mimics) were bitten more often by the lizard $\left(\chi^{2}=9.3 ; p<0.001\right.$. In general, teeth marks belonged to T. torquatus; only one was pecked by a bird. T. torquatus lizards were more active during the second period of the day (Tab. 4).

We found 32 nests of Trachymymex sp. and one of Mycocepurus goeldii in an area of 2.5 ha, corresponding to a density of 13.2 Attini nests/ha., and $91 \%$ of the Attini nests had seeds of $S$. thomasiifolium. Most of the nests were on the edge of vegetation islands, or next to small groups of plants isolated in the sandy soil.

The two Myrmicinae ants (Attini tribe) Trachymymex sp. and Mycocepurus goeldii are both active at dusk and during the night. The ants removed pieces of ripe fruit containing seeds from plants or on the ground and placed seeds around their nests (Fig. 2F). Ants also collected pieces of fruit or peels with seeds rejected or fallen under perches of frugivorous birds. The mean minimal dispersal distance of $S$. 
A

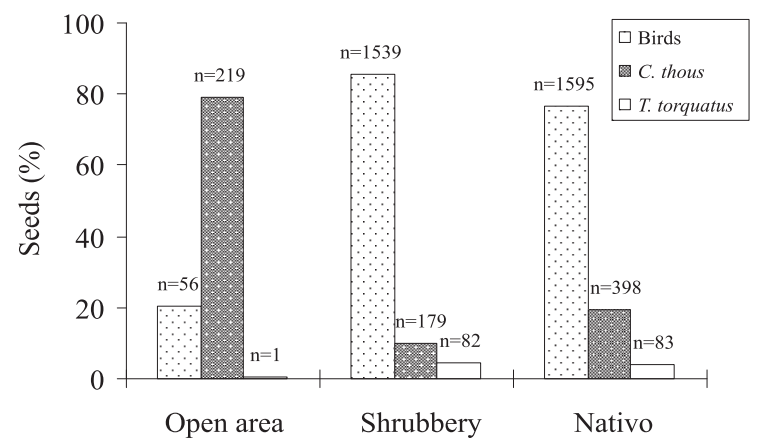

B

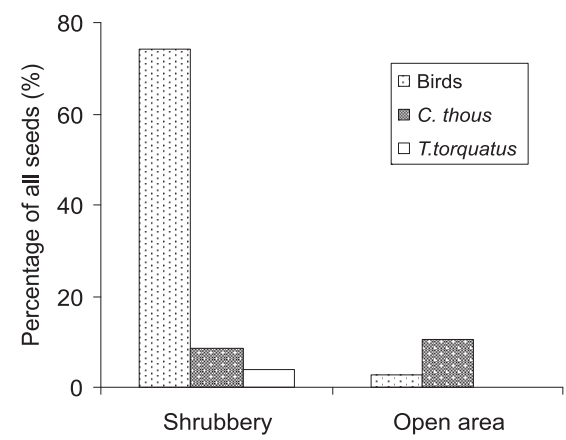

Figure 3 (A-B). (A) Percentage of $S$. thomasiifolium seeds in the faeces of birds, lizards (Tropidurus torquatus) and crab-eating fox (Cerdocyon thous) in shrubbery, open areas and both (Nativo). (B) Percentage of all S. thomasiifolium seeds in the frugivores' faeces in shrubberies $(n=1800)$ and open areas $(n=276)$.
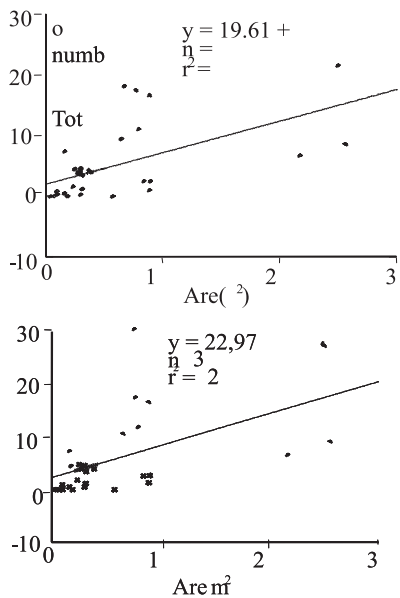

$\mathrm{D}$
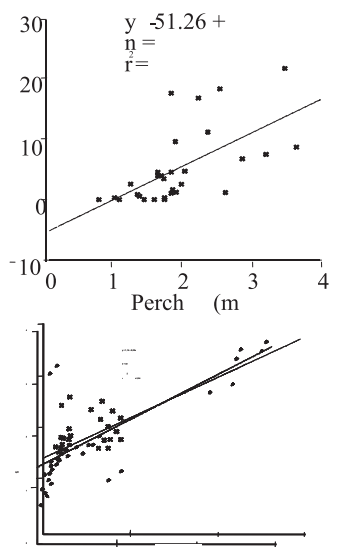

Figure 4. (A-D). (A) Correlation between the number of $S$. thomasiifolium seeds in birds" faeces and "Nativo" Shrubbery. (B)- Relation between the number of Solanum thomasiifolium seeds, in birds' faeces, and the perch height in the "Nativo" vegetation. (C) - Correlation between the total number of $S$. thomasiifolium seeds in birds" faeces and "Nativo" Shrubbery. (D) - Correlation between perch height and the area $\left(\mathrm{m}^{2}\right)$ of the shrubbery.
Table 4. Number of $S$. thomasiifolium fruits removed, number of models bitten when placed under plants and activity of Tropidurus torquatus (lizard). $\mathrm{X}=$ Beginning of the experiment.

\begin{tabular}{|c|c|c|c|c|c|}
\hline & \multicolumn{5}{|c|}{ Time } \\
\hline & $8: 30$ & 9:30 & $10: 30$ & 11:30 & $12: 30$ \\
\hline Fruits removed & $\mathbf{x}$ & 7 & 29 & 6 & 19 \\
\hline Models removed: & & & & 0 & 1 \\
\hline $\begin{array}{l}\text { By birds } \\
\text { By lizards }\end{array}$ & & & $\mathbf{X}$ & 3 & 9 \\
\hline Number of Tropidurus torquatus & $\mathbf{x} 0$ & 1 & 0 & 2 & 7 \\
\hline
\end{tabular}

thomasiifolium was $2.45 \pm 2.31 \mathrm{~m}$. The maximum dispersal distance recorded was $6.5 \mathrm{~m}$. In addition, Attini ants cut and removed approximately $3.8 \%$ of the ripe fruits covered with voile, during our estimate of ripe fruit availability on plants and on the ground (Tab. 2B).

The frugivores showed different types of foraging activity and, as a result, tended to deposit faeces with seeds in open areas and among shrubs. All S. thomasiifolium seeds found in frugivores faeces were intact. These seeds were found more frequently in areas with shrubbery $(86.7 \%)$ than in open areas (13.3\%), (Fig. 3), at a density of 9.9 seeds $/ \mathrm{m}^{2}$ and $1.6 \mathrm{seeds} / \mathrm{m}^{2}$, respectively.

Seeds were found in all bird faeces, in $87 \%$ for $C$. thous and in $51.9 \%$ for T. torquatus. The relative contribution of these frugivores to the total number of seeds found in the 'nativo' vegetation was $76.8 \%$ for birds, $19.2 \%$ for C. thous and $4 \%$ for $T$. torquatus. In the shrubbery, the seeds in bird faeces accounted for $85.5 \%$ of the total number, while in open areas seeds in C. thous faeces accounted for $79.4 \%$ of the total number (Fig. 3 A). The mean number of seeds in the faeces was larger for the crab-eating fox and smaller for the lizard (Tab. 5).

Table 5. Number of S. thomasiifolium seeds in birds, lizard (T. torquatus) and crab-eating fox (Cerdocyon thous) faeces in open areas and shrubberies in "Nativo" areas.

\begin{tabular}{lccc}
\hline Frugivores & $\begin{array}{c}\text { Number of } \\
\text { intact faeces }\end{array}$ & $\begin{array}{c}\text { Total number } \\
\text { of seeds }\end{array}$ & $\mathrm{X} \pm \mathrm{SD}$ \\
\hline Birds & 24 & 146 & $6.08 \pm 2.16$ \\
Tropidurus torquatus & 28 & 83 & $2.96 \pm 2.74$ \\
Cerdocyon thous & 20 & 398 & $19.9 \pm 25.88$ \\
\hline
\end{tabular}

The total number of seeds in bird faeces increased with shrubbery area (Fig. 4A; $\mathrm{r}^{2}=0.32 ; \mathrm{p}<0.001$ ) and perch height (Fig. 4B; $r^{2}=0.37, p<0.001$ ). The total number of seeds found in the shrubbery (Fig. $4 C ; r^{2}=0.28, p<0.003$ ) and perch height (Fig. 4D; $\mathrm{r}^{2}=0.54, \mathrm{p}<0.001$ ) increased with the size of the shrubbery.

Seeds from lizard faeces had significantly greater germination $(80 \%)$ and those from crab-eating fox, the smallest (53\%). The germination rate for seeds from bird faeces was $64 \%$ and did not differ significantly from that of control fruits (Fig.5). The germination rates of seeds from fruit (control), bird droppings, and faeces of crab- 


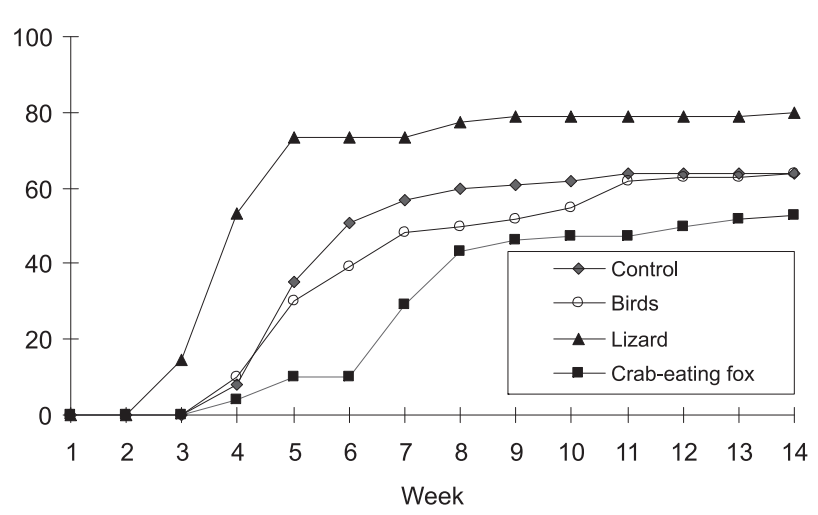

Figure 5. The germination rate for S. thomasiifolium seeds. Significant differences were observed between seeds from lizard and birds' faeces, using by the Kolmogorov-Smirnov test: $\mathrm{D}=0.51>\mathrm{D}_{0.01}=0.27$; lizard and crab-eating fox: $\mathrm{D}=0.73>\mathrm{D}_{0.01}=0.29$; lizard and control: $\mathrm{D}=0.55 \gg \mathrm{D}_{0.01}=0.27$; control and crab-eating fox: $\mathrm{D}=0.61>>\mathrm{D}_{0.01}=0.30$; birds and crab-eating fox: $\mathrm{D}=0.42$ $>\mathrm{D}_{0.01}=0.30$ but no significance between the control and birds: $\mathrm{D}=0.19<$ $\mathrm{D}_{0.01}=0.29$ and $\left.\mathrm{D}_{0.05}=0.24\right)$.

eating foxes and lizards were, respectively, $64,64,53$, and $80 \%$. The germination rates differed only between seeds from faeces of crab-eating foxes and lizards $\left(\chi^{2}=8.45 ; \mathrm{p}\right.$ $<0.001)$. The non-parametric Kolmogorov-Smirnov test used to compare germinability (cumulative curves) showed differences between seeds from lizard and bird faeces, lizard and crab-eating fox; lizard and control; control and crabeating fox; birds and crab-eating fox, but no significance between the control and birds.

Likewise, from July 1989 to January 1995, no recruitment of $S$. thomasiifolium was observed in the "nativo". In contrast, there was massive recruitment after the fire in January 1995. In July, the number of young plants growing next to old shrubberies was very large. Nevertheless, from 1996 to 1999, although many viable seeds were deposited, especially in the vegetation islands, (Fig. 3, 4), no recruitment was observed during these four years.

\section{Discussion}

The morphological characteristics of S. thomasiifolium - especially size, colour and arrangement of fruits - meant that birds were the main frugivores. Ripe fruits remained on the plant for at least one week, and were generally removed by birds in flight. Fruits were later consumed on perches. Characteristics such as maturation rate, fruit accessibility, number, and spatial distribution are important elements in the selection of fruit by frugivorous birds (Gautier-Hion et al. 1985). The quantity and position of the fruit influenced its visibility and its foraging costs for birds, and increased the probability of the plant being discovered and visited. The foraging cost varies with the distance required to reach the fruit, and it is proportional to the energy, time and/or risk of damage (Denslow et al. 1986).

S. thomasiifolium fruit was part of the diet of other species, such as T. torquatus (lizard) and C. thous (crab- eating fox). Because of its nocturnal habits, the crab-eating fox fed on the fruit at night. Although birds are important agents in the dispersal of tropical fruits, carnivores can also enrich their diet with fruits (Whitmore 1984). This was the case of the crab-eating fox in the 'nativo' vegetation. According to Facure \& Giaretta (1996), the crab-eating fox's diet in this particular forest consists of plants (43\%) mainly fruits, including Solanum americanum, insects (37 $\%)$ and vertebrates $(20 \%)$. In another locality, this canid fed mainly on a miscellany of fruits, and during the winter it fed mainly on insects (Bueno \& Motta-Junior 2004). We cannot discard the possibility of other mammals feeding on fruit that fell on the ground.

Lizard (T. torquatus) fed on ripe fruit that fell on the ground, which corresponded to approximately $4 \%$ of the ripe fruits that were produced. Although the entire fruit was eaten, some of the seeds were occasionally regurgitated along with the peduncle, with the remaining seeds eliminated in the faeces. The percentage of ripe fruit (4\%) that fell on the ground was equivalent to the percentage of S. thomasiifolium seeds found in the faeces of this lizard, relative to the total number of seeds dispersed by frugivores. Although T. torquatus preys on insects, it also feeds on fruits as mentioned by Figueira et al. (1994) and Fialho et al. (2000). Although few studies have dealt with seed dispersal by lizards (Traveset 1995; Olesen \& Valido 2003), these animals are considered to be important seed dispersers, especially in communities where herbivores are dominant (Irverson 1985).

Attinae ants carry pieces of pulp, seeds and peel with seeds to their nests, and $S$. thomasiifolium seeds were found around the nests of these ants. Seed dispersal by these ants can be considered primary if fruit pieces are collected directly from the plant, or secondary if collected under the plant or under bird perches. Ant seed dispersal distances are typically small, averaging less than $1 \mathrm{~m}$ (Gómez \& Spandaler 1998), and in this study the average seed dispersal distances for $S$. thomasiifolium were 2.45 $\mathrm{m}$. Benefits of seed dispersal by ants to the plant vary widely across plant species. Most documented cases fall into three categories; the plant benefits because: (i) seeds are deposited underground and, thus, are protected from fire; (ii) seeds are deposited in a nest microhabitat superior (in terms of nutrients or water) to microhabitats occupied by non-dispersed seeds; or (iii) seeds are moved from areas of high to low seed predation rates (Beattie 1985). Ants deposited the seeds of S.thomasiifolium in the nest, around the rejection pile which is rich in nutrients. This pioneer plant grows better in rich than poor sandy soil in the "nativo" vegetation.

Birds were the main dispersers of $S$. thomasiifolium fruits and removed approximately $20 \%$ of fruits every day. From the 10 frugivorous species that fed on $S$. thomasiifolium, the most frequent and abundant were Euphonia violacea and E. xanthogaster. These birds generally carried the 
fruit to perches to eat and then eliminate the intact seeds. These species could therefore contribute to the dispersal of S. thomasiifolium and to the enrichment of the "nativo" seed bank, or they could transport seeds to other areas. The movement and behaviour of frugivorous birds in fragmented areas are particularly important for the dispersal of seeds among different areas (Guevara \& Laborde 1993).

Seeds are not scattered, since their dispersal depends on the behaviour of dispersers (Howe \& Smallwood 1982). The site of S. thomasiifolium seed deposition depends on the behaviour of the frugivores. The deposition of seeds in the "nativo" vegetation was approximately six-fold greater in shrubby areas $\left(9.9 \mathrm{seeds} / \mathrm{m}^{2}\right)$ than in open areas $(1.6$ seeds/ $\mathrm{m}^{2}$ ). In open areas, the sandy soil is exposed and can reach $56^{\circ} \mathrm{C}$ (Figueira et al. 1994), which could cause the death of the seed embryo. The characteristics of this shrubbery such as its microclimate and high organic matter rate suggest that it provides appropriate sites for the seeds to germinate and for the seedlings to establish themselves. Despite these conditions, from 1996 to 1999 , there was no recruitment of $S$. thomasiifolium individuals in the population, and the density of this plant decreased, while other species established themselves.

The reproductive characteristics of $S$. thomasiifolium are similar to those of pioneer species. These species show intense fruit production, with a large number of seeds, and usually some form of dormancy, that helps them to remain viable for long periods. Among neotropical pioneer species, there is a predominance of positive photoblastic dormancy (Whitmore 1984). According to Charles-Dominique (1986), these species require a high exposure to light in order to germinate, and normally, they have a short life span. In tropical regions with well-established dry and wet seasons, dormancy is broken in the dry season so that germination occurs at the beginning of the rainy season (Baskin \& Baskin, 1998). However, the lack of germination and recruitment in the field in the four subsequent years was probably linked to other factors such as the positive photoblastism of the seeds.

The rapid colonization of $S$. thomasiifolium in the "nativo" after the fire corroborates its pioneer characteristic and indicates that the seeds were probably dormant in the seed bank. According to Baskin and Baskin (1998), some Solanaceae accumulate and persist in the seed bank for many years. S. nigrum seeds remain viable in soil up to 16 yrs (Robert \& Neilson 1981).

The S. thomasiifolium seeds present in the "nativo" seed bank were placed there mainly by birds. The clustered distribution of this species around the shrubbery (J. Vasconcellos-Neto, pers. obs.) reveals a direct relationship with perch height. This may indicate that open areas are less favourable for the seedlings to become established. On the other hand, the shrubberies have microclimatic conditions that are more adequate for plant establishment as well as more organic matter, and possibly higher levels of nutrients, which the fire may have released.
The correlation with perch height may be a consequence of a better visualization and greater frequency of perch usage by birds. This observation reinforces the importance of perches for the colonization of open areas. Perches may have a remarkable effect on the rate and pattern of regeneration in open areas (Wilson \& Crome 1989). In studies on the dispersal of propagules by birds, Guevara \& Laborde (1993) concluded that large isolated trees represented more favourable environments for the germination and establishment of trees, and that the large number of seeds found under their canopy resulted from seed deposition by frugivorous birds. The efficiency of perches was also observed in abandoned pastures in central (Miriti 1998) and eastern (Nepstad et al. 1998) Amazon, where there is a higher seed density under perches than in other areas.

The germination rate of $S$. thomasiifolium seeds that passed through the gut of lizards (T. torquatus - 80\%), birds (64\%), crab-eating fox (C.thous - 53\%) and the controls (64\%) differed significantly, except between birds and controls. Lizards enhanced the germination of S. thomasiifolium seeds, which indicated that they were important dispersers in the "nativo". In this same area, Figueira et al. (1994) reported that these lizards fed on Melocactus violaceus fruit and that the seeds only germinated after passing through the gut. $T$. torquatus was also described as being an important disperser on the southeastern coast of Brazil (see revision by Olesen \& Valido 2003). Although birds and crab-eating foxes do not speed up the germination rate, they carry the seeds farther. All of these frugivores are fundamental in the colonization of "nativo" by S. thomasiifolium.

Frugivorous vertebrates may affect plant fitness by dispersing seeds to favourable sites and by altering germination rates by passing seeds through their guts (Samuels \& Levey 2005). Rodriguez-Perez et al. (2005) showed great heterogeneity in seed-emergence responses of different plant species to ingestion by different types of frugivores, and to different experimental conditions. In our experiments seed germination rates were accelerated in relation to control (seeds from the fruit) when passing through the gut of lizard and delayed when passing through the gut of eating-crab-fox. In spite of these results in laboratory conditions, no recruitment was observed in the field during the following four years.

Frugivores are responsible for the seed rain that enables the mother plant to place seeds in locations that are appropriate for germination. According to Barnea et al. (1992), frugivores decrease the density of seeds, thereby reducing the level of intra- and inter-specific competition and enhancing the establishment of the seedling.

In conclusion, plant architecture, fruit productivity, fruit characteristics and the diversity of frugivores are important in the success of $S$. thomasiifolium in the colonization of the habitat studied. 


\section{Acknowledgments}

This study was performed during a Field Course in Ecology. We thank Newton Leal Filho, Lenice Medeiros, Valéria dos Santos Moraes, Paula Cabral Eterovick, Hermes Fonsêca de Medeiros and Tarcísio da Silva Santos Júnior for helping us with sampling and discussing the data, Pilar Fernández for helping with the field work, and UNICAMP and the Companhia Vale do Rio Doce (CVRD) for the logistic support. Dr. Alejandro Velázquez (UNAM, México), Dr. João Renato Stehmann (UFMG), Dr. João Semir and Dra. Eleonore Setz (UNICAMP) for reading the first version of this manuscript and providing relevant suggestions. This work was supported by the M.B. Foundation, CAPES and CNPq. L.B.A. was supported by CAPES.

\section{References}

Alexandre, D.Y. 1982. La dispersion de Solanum verbascifolium em cote-d'ivoire: role dês Cephalophes. Review de Ecologie (Terre Vie) 36: 293-295.

Ávila, M.L.; Hernandez, V.H. \& Velarde, E. 1996. The diet of Resplandent quetzal (Pharomachrus mocinno mocinno: Trogonidae) in a Mexican clourd. Biotropica 2: 720-727.

Barnea, A.; Yom-Tov, Y \& Friedman, J. 1992. Effect of frugivorous birds on seed dispersal and germination of multi-seeded fruits. Acta Oecologica 13: 209-219.

Baskin, C.C. \& Baskin, J.M. 1998. Seeds: ecology, biogeography and evolution of dormancy and germination. Academic Press, San Diego.

Beattie, A.J. 1985. The Evolutionary Ecology of Ant-Plant Mutualisms. Cambridge University Press, Cambridge.

Bueno, A.D. \& Motta-Junior, J.C. 2004. Food habits of two syntopic canids, the maned wolf (Chrysocyon brachyurus) and the crab-eating fox (Cerdocyon thous), in southeastern Brazil. Revista Chilena de Historia Natural 77: 5-14

Castro, E.R. de \& Galleti, M. 2004. Frugivoria e dispersão de sementes pelo lagarto teiú Tupinambis merianae (Reptilia: Teiidae). Papéis Avulsos de Zoologia (São Paulo) 44: 91-97.

Charles-Dominique, P. 1986. Inter-relations between frugivorus vertebrates and pioneer plants: Cecropia, birds and bats in French Guyana. Pp 119-135. In: A. Estrada \& T.H. Fleming (eds.). Frugivores and Seed Dispersal. Dr. W. Junk Publishers, Dordrecht.

Charles-Dominique P; Atramentowicz, M.; Charles-Dominique, M.; Gerard, H.; Hladik, A. \& Prévost, M.F. 1981. Les mammifères frugivores arboricoles nocturnes d'une forêt guyanaise: inter-relations plantesanimaux. Review de Ecologie (Terre et Vie) 35: 341-435.

Dawson, E.Y. 1962. The giants of Galapagos. Natural History 71: 52-57.

Denslow, J.S.; Moermond,T.C. \& Levey, D.J. 1986. Spacial components of fruit display in understory trees and shrubs. Pp 37-44. In: A. Estrada \& T.H. Fleming (eds.). Frugivores and Seed Dispersal. Dr. W. Junk Publishers, Dordrecht.

Facure, K.G.\& Giaretta, A.A. 1996. Food habits of carnivores in a coastal Atlantic forest of southeastern Brazil. Mammalia 60: 499-502.

Fialho, R.F.; Rocha, C.F.D. \& Vrcibradic, D. 2000. Feeding ecology of Tropidurus torquatus: Ontogenetic shift in plant consumption and seasonal trends in diet. Journal of Herpetology 21: 307-316.

Figueira, J.E.C.; J Vasconcellos-Neto, J; Garcia, M.A. \& Souza, A.L.T. 1994. Saurocory in Melocactus violaceus (Cactaceae). Biotropica 26: $295-301$.

Galindo-González, J. 1998. Dispersión de semillas por murciélagos: su importancia en la conservación y regeneración del Bosque Tropical. Acta Zoologica Mexicana 73: 57-74.

Gautier-Hion, A.; Duplantier,J.M.; Quris,R.; Feer, F.; Sourd, C.; Decoux, J.P.; Dubost, G.; Emmons, L.; Erard, C.; Heckestweiler, P.; Moungazi, A.; Roussilhon, C. \& Thiollay, J.M. 1985. Fruit characters as a basis of fruit choice and seed dispersal in a tropical forest vertebrate community. Oecologia 65: 324-337.

Gómez, C. \&, Espalander, X. 1998. Myrmecochorous dispersal distances: A world survey. Journal of Biogeography 25: 573-80.

Guevara, S. \&, Laborde, J. 1993. Monitoring seed dispersal at isolated standing trees in tropical pastures: consequences for local species availability. Pp 319-338. In: T.H. Fleming \& A. Estrada (eds.). Frugivory and seed dispersal: ecological and evolutionary aspects. Vegetatio107/108, Kluwer Academic Publishers, Dordrecht.
Heinsdijk, D.; Macedo, J.G.; Andel, S. \& Ascoly, R.B. 1965. A floresta do norte do Espírito Santo. Boletim do Departamento de Recursos Naturais Renováveis do Ministério da Agricultura 7: 4-68.

Howe, H.F.; \& Smallwood, J. 1982. Ecology of seed dispersal. Annual Review of Ecology and Systematics 13: 201-228.

Howe, H.F. \& Westley, L.C. 1988. Ecological relationships of plants and animals. Oxford University Press. New York, Oxford.

Iudica, C.A. \& Bonaccorso, F.J. 1997. Feeding of the bat, Sturnira lilium, on fruits of Solanum riparium influences dispersal of this pioneer tree in forests of northwestern Argentina. Studies in Neotropical Fauna and Environment 32: 4-6.

Irverson, J.B. 1985. Lizards as seed dispersers? Journal of Herpetology 19: 292-293.

Izhaki, I.; Korine, C. \& Arad, Z. 1995. The effect of bat (Rousettus aegyptiacus) dispersal on seed germination in eastern Mediterranean habitats. Oecologia 101: 335-342.

Levey, D.J. 1986. Methods of seed processing by birds and seed deposition patterns. Pp. 147-158. In: A. Estrada \& T.H. Fleming (eds.) Frugivores and seed Dispersal. Dr. W. Junk Publishers, Dordrecht.

Marinho-Filho, J. S. \& Vasconcellos-Neto, J. 1994. A dispersão de sementes de Vismia cayennensis (Jacq.) Pers. (Guttiferae) por morcegos na região de Manaus, Amazonas. Acta Botanica Brasilica 8: 87 -96.

Martínez Del Rio, C \& Restrepo, C. 1993. Ecological and behavioral consequences of digestion in frugivorous animals. Pp. 205-216. In: T.H. Fleming \& A. Estrada (eds.). Frugivory and seed dispersal: ecological and evolutionary aspects. Vegetatio107/108. Kluwer Academic Publishers, Dordrecht.

Miriti, M.N. 1998. Regeneração florestal em pastagens abandonadas na Amazônia central: competição, predação e dispersão de sementes. Pp. 179-190. In: C. Gascon \& P. Moutinho (eds.). Floresta Amazônica: dinâmica, regeneração e manejo. Ministério Ciência e Tecnologia/ INPA, Manaus, Brasil.

Murray, K.G.; Russell, S.; Picone, C.M.; Winnettmurray, K.; Sherwood, K. \& Kuhlmann, M.L. 1994 Fruit laxatives and seed passage rates in frugivores - consequences for plant reproductive success. Ecology 75: 989-994.

Nepstad, D.C.; Uhl, C.; Pereira, C.A. \& Silva, J.M.C. 1998. Estudo comparativo do estabelecimento de árvores em pastos abandonados e florestas adultas da Amazônia oriental. Pp. 191-218. In: C. Gascon \& P. Moutinho (eds.). Floresta Amazônica: dinâmica, regeneração e manejo. Ministério Ciência e Tecnologia/INPA, Manaus, Brasil.

Nogales, M.; Delgado, J.D. \& Medina, F.M. 1998. Shrikes, lizards and Lycium intricatum (Solanaceae) fruits: a case of indirect seed dispersal on an oceanic island (Alegranza, Canary Islands). Journal of Ecololgy 86: $866-871$.

Nogales, M.; Hernandez, E.C. \& Valdes, F. 1999. Seed dispersal by common ravens Corvus corax among island habitats (Canarian Archipelago). Ecoscience 6: 56-61.

Olesen, J.M. \& Valido, A. 2003. Lizards as pollinators and seed dispersers: an island phenomenon. Trends in Ecology and Evolution 18: 177-181.

Passos, C.F.; Silva, W.R.; Pedro, W.A \& Bonin, M.R. 2003. Frugivoria em morcegos (Mammalia, Chiroptera) no Parque Estadual Intervales, sudeste do Brasil. Revista Brasileira de Zoologia 20: 449-458.

Peixoto A.L. \&, Gentry, A. 1990. Diversidade e composição florística da mata de tabuleiro na Reserva Florestal de Linhares (Espírito Santo, Brasil). Revista Brasileira de Botânica 13: 19-23.

Pijl, L. Van Der 1972. Principles of dispersal in higher plants. Editora Springer-Verlag, New York.

Rick, C.M. \& Bowman, R.L. 1961. Galapagos tomatoes and tortoises. Evolution 15: 407-417.

Robert, H.A.; \& Neilson, J.E. 1981 Seed survival and periodicity of seedling emergence in twelve weedy species of Compositae. Annals of Applied Biology 94:111-120.

Rodriguez-Perez, J.; Riera, N. \& Traveset, A. 2005. Effect of seed passage through birds and lizards on emergence rate of mediterranean species: differences between natural and controlled conditions. Functional Ecology 19: 699-706.

Rowell, T.E. \& Mitchell, B.J. 1991. Comparison of seed dispersal by guenons in Kenya and capuchins in Panama. Journal of Tropical Ecology 4: 269-274. 
Samuel, I.A. \& Levey, D.J. 2005. Effects of gut passage on seed germination: do experiments answer the questions they ask? Functional Ecology 19: $365-368$.

Schupp, E.W. 1993. Quantity, quality and the effectiveness of seed dispersal by animals. Pp.15-29. In: T.H. Fleming \& A. Estrada (eds.). Frugivory and seed dispersal: ecological and evolutionary aspects. Vegetatio 107/108. Kluwer Academic Publishers, Dordrecht.

Sinha, A. \& Davidar, P. 1992. Seed Dispersal of a wind Dispersed Rain Forest Tree in the Western Ghats, India. Biotropica 24: 519-525.

Sokal, R.R. \& Rohlf, F.J. 1995. Biometry. W. H. Freeman and Company, New York.

Stiles, E.W. \& White, D.W. 1986. Seed deposition patterns: influences of season, nutrientes, and vegetation structure. Pp. 45-54. In: A. Estrada \& T.H. Fleming (eds). Frugivores and seed dispersal. Dr. W. Junk Publishers, Dordrecht.

Symon, D.E. 1979. Fruit diversity and dispersal in Solanum in Australia. Journal of Adelaide Botanical Garden 1: 321-331.
Tabarelli, M.; Mantovani, W. \& Peres, C.A. 1999. Effects of habitat fragmentation on plant guild structure in the montane Atlantic forest of southeastern Brazil. Biological Conservation 91: 119-127.

Traveset, A. 1995. Seed dispersal of Cneorum tricoccon L. (Cneoraceae) by lizards and mammals in the Balearic islands. Acta Oecologica 16: $171-178$

Uieda, W. \& Vasconcellos-Neto, J. 1985. Dispersão de Solanum spp. (Solanaceae) por morcegos, na região de Manaus-AM. Revista Brasileira de Zoologia 2: 449-458.

Vasconcellos-Neto, J.; Souza, A.L.T.; Faria, D.M. \& Guimarães, M.M. 2000. Effects of colour, shape and location on removal rates of cactus fruits by a neotropical lizard: an experimental study. Journal of Herpetology 34: 306-309.

Whitmore, T.C. 1984. Tropical rain forest of the far east. Clarendon Press, Oxford.

Wilson, M.F. \& Crome, F.H.J. 1989. Patterns of seed rain at the edge of a tropical Queensland rain forest. Journal of Tropical Ecology 5: 301-308. 